\title{
Innovation of Local Government in Improving Food Security in Pacitan Regency
}

\author{
Burhanudin Mukhamad Faturahman, Sarwono \& Mochamad Rozikin \\ Master of Administrative Science Program, \\ Faculty of Administrative Science, \\ Universitas Brawijaya, Indonesia \\ burhanmfatur@gmail.com
}

\begin{abstract}
Innovation needed in the public sector to serve the needs in the community, especially for food. Innovation in meeting the food requirements is realized through diversification of nonrice food by developing the potential of the region, namely the tubers as an alternative source of carbohydrates. The results of descriptive qualitative research showed that tubers abundant amount of production, but is still simple processing with the processed chips, not in the form of processed varied. Marketing difficulties because there is no clear target market. Innovation is realized through a special pilot project of planting tubers, support equipment processing the tubers are managed by Fostering Family Welfare(PKK) in the village. Actors involved, namely the Office of Food Security, Department of Food Crops and Livestock, the Energy assistant village, the PKK village and household industries. Impact on earnings is not optimal, overlapping authority at the local government level and the processing has not been sustained. Therefore, the development model tubers clarified the authority of institutions at the local government level and rural level.

Keyword: Local Government Innovation, Group of PKK, Food Security, Diversification, Institutional.
\end{abstract}




\section{International Journal of Management and Administrative Sciences (IJMAS)}

(ISSN: 2225-7225)

Vol. 4, No. 06, (70-75)

www.ijmas.org

\section{INTRODUCTION}

The local government in implementing development based on Act No. 23/2004 directed to accelerate the realization of community welfare through service, empowerment and community participation. But in the implementation of the development there are general problems in developing available local resources.

The development of local resources need new ways of effective way to meet the needs of the community so that innovation needs to be done by the local government. Innovation according to the Muluk (2008:43) is an instrument to develop a new way related to the use of resources and to meet the needs of the community effectively. Remember the resources each different area, hence development which is done at the central level to the local level is not always the same.

The development efforts in the area cover many things one only food development. Pacitan Regency based on Regional Gross Domestic Product of the year 2014 is the building is dominated by the agricultural sector, forestry and fishing as much as $34.7 \%$, while the basic food ingredients dominate the agricultural sector of $39.8 \%$. But during this food consumption of rice is still high. However, during this food consumption of rice is still high than alternative tubers food. As in the table below:

Table 1. The availability of food and Real Consumption (Tonnes) PacitanRegencyin 2010-2015

\begin{tabular}{|l|l|c|c|c|c|c|c|}
\hline \multirow{2}{*}{ No } & \multirow{2}{*}{ Database } & \multicolumn{6}{c|}{ Years } \\
\cline { 3 - 8 } A & Availability & 2010 & 2011 & 2012 & 2013 & 2014 & 2015 \\
\hline 1 & Rice & 96.710 & 98.658 & 100.031 & 111,241 & 112.930 & 116.717 \\
\hline 2 & Corn & 108.761 & 94.353 & 121.550 & 145.370 & 85.201 & 102.256 \\
\hline 3 & Sweet Potato & 704 & 706 & 1.015 & 449 & 465 & 224 \\
\hline 4 & Cassava & 434.975 & 479.771 & 533.202 & 598.437 & 338.672 & 381.531 \\
\hline 5 & Brown Sugar & 11.441 & 10.165 & 10.167 & 10.276 & - & 20.765 \\
\hline 6 & Peanut & 8.720 & 8.582 & 8.533 & 10.309 & 8.130 & 6.381 \\
\hline 7 & Soy & 3.160 & 3.760 & 3.621 & 3.463 & 49.140 & 6.026 \\
\hline 8 & Meat & 1.905 & 1.959 & 1.940 & 1.902 & 1.956 & 2.466 \\
\hline 9 & Egg & 289 & 293 & 295 & 581 & 311 & 373 \\
\hline 10 & Fish & 4.828 & 5.467 & 5.956 & 5.956 & 5.132 & 8.521 \\
\hline B & Real Consumption & & & & & & \\
\hline 1 & Rice & 52.708 & 38.478 & 67.447 & 45.402 & 45.565 & 58.878 \\
\hline 2 & Corn & 3.598 & 151 & 1.904 & 1.985 & 2.354 & 2.408 \\
\hline 3 & Sweet Potato & 1.195 & 292 & 615 & 676 & 691 & 698 \\
\hline 4 & Cassava & 6.681 & 1.509 & 19.059 & 2.260 & 3.369 & 3.431 \\
\hline 5 & Brown Sugar & 173 & 1.157 & 1.164 & 63 & 65 & 66 \\
\hline 6 & Peanut & 391 & 595 & 598 & 211 & 216 & 219 \\
\hline 7 & Soy & 5.883 & 2.753 & 2.769 & 11.699 & 11.965 & 33.575 \\
\hline 8 & Meat & 2.721 & 346 & 1.670 & 2.914 & 2.980 & 2.941 \\
\hline 9 & Egg & 3.028 & 1.725 & 2.502 & 3.463 & 2.980 & 3.503 \\
\hline 10 & Fish & 7.944 & 9.135 & 6.277 & 7.243 & 3.542 & 8.818 \\
\hline
\end{tabular}

Source: Food Security Office Pacitan Regency 2015

Based on the data, food consumption in Pacitan Regency was still dominated by rice food while food roots good sweet potato and cassava still low. However the potential availability of plant roots is relatively large compared to the rice. Therefore innovation in the improvement of food security in the region needs to be done to take advantage of the potential in the area. The system innovation in a special area for food in Pacitan Regency has been regulated in the Regulation of Pacitan Regent No. 31 The year 2014 refers to the mission to 4 about the improvement of the economy hinges on the leading sector with food availability target areas.

Tubers can be used as an alternative food because it contains carbohydrates. The problems faced with the existence of roots has not yet been counted and has not been managed well. This is because the plant is 
still growing wild and some have grown community. In addition, program of developing roots in the area from the province so that the initiative from the districts are perceived to be less. PacitanRegency also does not have regulations governing the Regent development of non-rice food especially tubers.

The Food Security Office in Pacitan Regency an executive development program for food in the region must have the innovation to raise the diversity of food in addition to food of rice by involving local communities in the area of development. Given the importance of local government innovation in the improvement of food security and the author of the formulate problem how processing plant roots by the community in Pacitan Regency and how the local government innovation in the improvement of food security tuber crops in Pacitan Regency and how the model of innovation development of plant tubers.

The purpose of this research is to describe and analyze the processing plant tubers by the community and local government innovation in the improvement of food security and provide the model of innovation development of plant tubers. The Benefits of research for Pacitan Regency government as a reference planning for food in the improvement of food security in Pacitan.

\section{RESEARCH METHODS}

The type of research using descriptive type with qualitative approach. The type of descriptive means making the description related to the situation or events. According to qualitative Sarwono (2006:193) is a process of understanding of the complexity of the interaction of man.

The focus of this research namely 1) processing roots during this 2) innovation regional government in improving food security tubes in Pacitan Regency. 3) Development innovation model of tubers.

The location of the research is located in Pacitan Regency and research sites on the food security Office in Pacitan Regency. The technique of selection of informants through a snowball. Data Source the primary data and secondary data. Data collection through interview, observation and documentation. The research instrument in the form of researchers own guidelines, interview and note the field. Analysis of the data using the interactive model Miles, Huberman and Saldana (2014:14) through the stages: data collection process, condensing data, presentation of data and the withdrawal of the conclusion, as shown below:

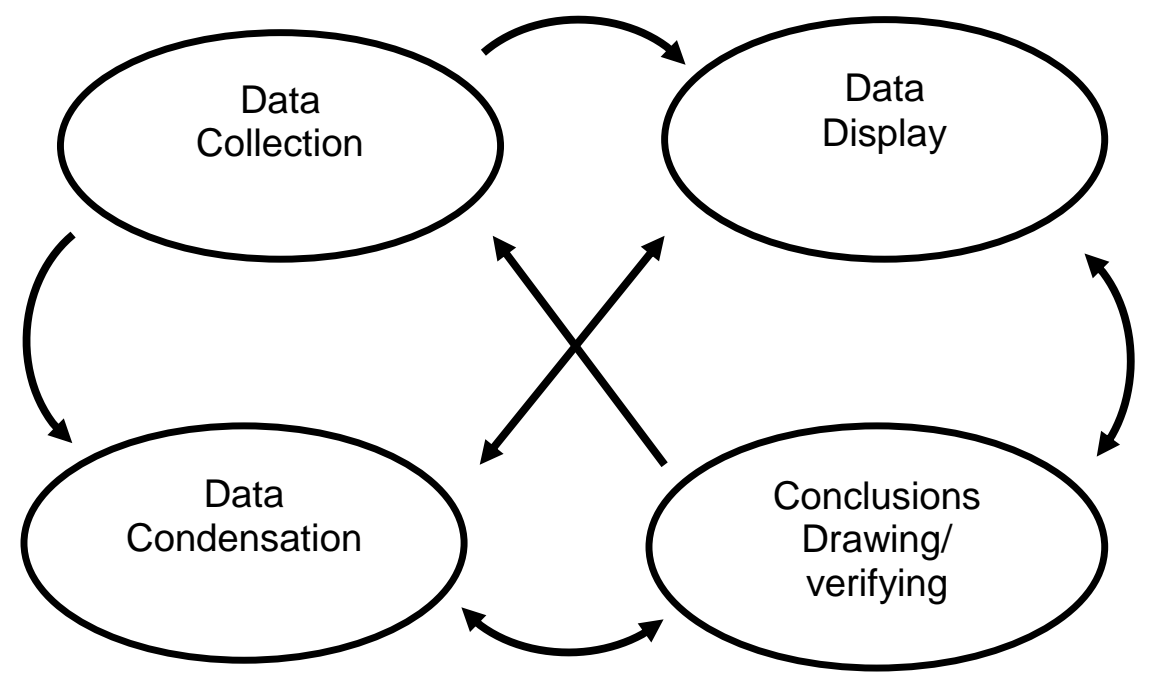

Figure 1. components of Data Analysis: Interactive Mpdel

Source: Miles, Huberman and Saldana, Qualitative Data Analysis A Methods Sourcebook Third Edition, SAGE Publication. Arizona State University, USA (2014:14) 


\subsection{Processing Tubers}

\section{RESULTS AND DISCUSSION}

Regional development according to the LAN is divided based on the flagship sector includes planning up to implementation is part of the national development (2008:62). Meanwhile, the sectoral approach by Tarigan (2012:36-39), namely economic activity grouped top sectors and analyzed for potential opportunities and taken along with the increase in activity and location. Development of the agricultural sector in Pacitan Regency consists subsector one is food. Food stuff especially the tubers in Pacitan Regency has a potential that could be upgraded because of the availability of abundant but consumption a little. That is because the processing of tubers during this is done in a simple way with the results of the processed products such chips where this product is the most dominant product. The treatment process is done manually. In processing the form which varies not done as the group PKK village development not get a sustained processing training.

Processing raw materials obtained from the harvest itself and some taken from the harvest citizen. This showed in the production, tubers has many planted by the host and used to eat material and partly to be sold around the village development. Although the tubers have many planted consumption level is still very low. Difficulty marketing tubers due to the lack of legal certainty marketing target for the harvest.

Local food processing as a whole from production to marketing is to bring up the diversity of food besides rice in PacitanRegency i.e. tubers. Many kinds of food besides rice as revealed Sumaryanto (2009:100) include corn, sorghum, tubers, nuts, seaweed and others. However, the local foodstuffs in Pacitan Regency that has the potential to be developed in order to maintain food security to the level of a household is the tubers as alternatives to substitute rice. According to Setiawan (2010:2) food security is sufficiently community food evenly and they can reach the level of a household includes a diversity of culturally appropriate food.

\subsection{Local Government Innovation to Improve Food Security Tubers Pacitan Regency}

Muluk (2008:43) explained that innovation is an instrument to develop various new ways in using resources and meet the needs of more effectively. While the public sector innovation Mugan and Albury (2003:5) carried out in the framework of problem solving and use of resources and technology in a way that is better. The goal, namely enhancing responsiveness to local needs and individually and give priority to the needs and expectations of the public. Innovation development of tuber foodstuffs according to the framework of the innovation Mulgan and Albury (2003) in Lekhi (2007:16) starts from stage 1) generalization of the idea of increased food security through diversity of local food, namely food security Office of PacitanRegency 2) incubating and prototyping 3 ) replication and scaling up 4) analyzing and learning.

Innovation development of tubers implemented by creating a special demplot planting tubers near the settlement. Villages that do not have land namely Bomo Village. Other innovations, encourage the community to consume tubers at the time of the dinner while the rice consumed at the time of the breakfast and day by day this in order to reduce the consumption of rice. The Office of Food Security also getting consume tubers in the morning. The form of development policy by giving the post-harvest processing comes from the province in the village of Piton, Bomo, Tinatar and Kebonsari to managed in groups. The processing tool is still not used optimally by groups because they have not received instructions from the facilitators.

The actors who were involved in the Office of food security, service food crops and livestock, facilitators, Group of PKK village development and the domestic processing industry. Overlapping authority at local government level occurs because of the lack of clarity of the mechanisms for the development of tubers are the priorities of the Center and the development of tubers locally. The development of tubers in Pacitan yet provides the impact for the improvement of the citizens income because the result is still a huge crimp in small scale and not in the form that vary. From the concept of innovation which has been described previously, innovation development of tubers has not been preparing the plan of the details of the implementation of but the idea and the idea of innovation has the similarity of the potential food tubers.

Daglio, et.al (2014:4) reveals the innovation leads to a novelity (renewal), implementation and impact. Food diversity is nothing new so that innovation to give effect to be effective, efficient and leads to the satisfaction of the users then updates the concept of ways that have been implemented can be done. It is aligned with Thoha in Noor (2013:85) that the local authorities in charge to serve the communities based on common interests, facilitate the Affairs and gives satisfaction to the public. Thus, Sikander (2014:174) services granted by the local authorities concerned need per day against many individuals in a 
comprehensive manner covering the Ministry of the environment (social protection and realization of public facilities) and personal services (services children school, the provision of hospital care, as well as other cases that helps social Department) including food needs. The provision of appropriate food needs of the potential that exists in the region need food in order fulfillment policy supported the condition fulfilment can food would be sure as expressed by Prayitno (1987:17) that the policy could be seen based on the import of certain commodities.

2.3 Development Innovation Model of Tubers in PacitanRegency.

The development of tubers in PacitanRegency done by topdown. Development activities and assistance from processing food security Agency East Java Province. Development activity is managed groups namely through a group of PKK village.

Based on the condition of the processing and innovations that done, model innovation development of tubers that in accordance with institutional strengthening at the village level and the local government level. Strengthen institutional arrangements at village level by involving existing institutions in rural areas such as the resilience of the village, cooperative Village Unit, Enterprises Village, and so on. Institutional Arrangements for local government level done with clear mechanisms for the development of roots to the handling of the priorities of the central and local government and the clarity of the agencies that deal with the production and processing of post-harvest.

\section{CONCLUSION}

The conclusion from the discussion above that the processing tubers in Pacitan during this is used for the ingredients with the results of the processed products that are still simple. Marketing of raw materials and the results of the processed products has yet to provide a significant advantage for the production of the community because there has been no definite market.

While the local government innovation through special land and help processing tool not yet completely optimal because there are villages that do not have special land development and the appliance has not been used with good processing. Suggestions from researchers namely development innovation model of tubers done by strengthening rural level institutional and local government level to development mechanism became clear and the authority does not overlap. 


\section{REFERENCES}

[1]. Daglio, M. Gerson D. Kitchen H. 2014.Innovating The Public Sector Innovation. From Ideas to Impact. Paris, OECD.

[2]. Lekhi, Rohit. 2007.Public Service Innovation: A Research for The Work Foundation's Knowledge Economy Programme. Manchester, Research Republic LLP.

[3]. Lembaga Administrasi Negara. 2008.Pembangunan Daerah, Sektor dan Nasional. Jakarta, LAN.

[4]. Miles, Matthew B, Huberman, A Michael, Saldana, Jhonny, 2014.Qualitative Data Analysis: A Methods Sourcebook. SAGE Publication.

[5]. Mulgan, Geoff and Albury, David. 2003.Innovation In The Public Sector. Accessed http://www.sba.oakland.edu/faculty/mathieson/mis524/resources/readings/innovation /innovation _in_the_public_sector.pdfin date 29 September 2016.

[6]. Muluk, Khairul M.R. 2008.Knowledge Management: Kunci Sukses Inovasi Pemerintahan Daerah. Malang, Bayumedia Publishing.

[7]. Noor, Tajuddin. 2013.Upaya Peningkatan Kinerja Pelayanan Perusahaan Daerah Air Minum Kepada Pelanggan di Kota Samarinda. Disertasi. Malang, Fakultas Ilmu Administrasi.

[8]. Prayitno, H. .1987.Pembangunan Ekonomi Pedesaan. Yogyakarta : BPFE.

[9]. Sarwono, J. .2006.Metode Penelitian Kuantitatif dan Kulaitatif. Yogyakarta: Graha Ilmu.

[10]. Setiawan, S., Y. 2010.Peningkatan Produksi Beras dan Diversifikasi Pangan Lokal Untuk Meningkatkan Ketahanan Pangan Nasional. Lomba penulisan Artikel Ilmiah Pertanian Berbasis Web TPB ITB. Accessedhttp://yogas09.student.ipb.ac.id/files/2010/12/ Diversifikasi-dan-Optimalisasi-PanganLokal-untuk-Meningkatkan-Ketahanan-Pangan-Nasional.pdfin date 16 January 2016.

[11]. Sikander, Tasneem. 2015. A Theoretical Framework Of Local Government. Pakistan, Government Viqar-un-Nisa Post Graduate College. Accessedhttp://www.ijhssnet.com/ journals/ Vol_5_No_6_1_June_2015/19. Pdf in date 4 October 2016.

[12]. Sumaryanto.2009.Divesifikasi Sebagai Salah Satu Pilar Ketahanan Pangan. Forum penelitlan Agro Ekonomi. Volume 27 No.2. Desember 2009: 93.108. Accessed pse.litbang.pertanian.go.id /ind/pdffiles/FAE27-2b.pdf in date 12 December 2014.

[13]. Tarigan, Robinson. 2012.Perencanaan Pembangunan Wilayah : ed. Revisi. Jakarta : PT. Bumi Aksara. 